\title{
Application of Point, Line and Plane in Landscape Design
}

\begin{abstract}
Levi Lee ${ }^{1, *}$
${ }^{1}$ Lasalle College of the Arts, Singapore 187940, Singapore

*Corresponding author. Email: lee47045081@ gmail.com

ABSTRACT

Point, line, and plane are the basic elements of plane composition. In landscape design, elements such as point, line, and plane are often materialized, replaced with specific landscape design elements, and then combined and designed according to the law of formal beauty. In landscape design, many points are gathered together to form the linearization and complanation of points; according to different shapes, lines can be divided into two types: straight lines and curves. A straight line has the characteristics of speed, strength and masculine beauty, and a curve has the characteristics of flexibility, softness, and feminine beauty; a plane is a trajectory or collection of points and lines, which can be divided into two forms: regular and irregular. Regular plane includes circular plane, triangular plane, square plane, polygonal plane, etc. The irregular plane is free in shape, with natural and unrestrained and random nature.
\end{abstract}

Keywords: point, line, plane

\section{INTRODUCTION}

As a basic design training method, plane composition can be traced back to the Bauhaus School of Design in Germany. However, due to the abstraction of plane composition, many landscape architects have a superficial understanding of point, line and plane, and cannot connect specific landscape design elements with abstract point, line and plane, and thus cannot apply the point, line and surface composition rule to concrete landscape design. Therefore, it has important practical significance to study the relationship between point, line and surface and specific elements of landscape design, and to explore the application of point, line and plane in landscape design.

\section{THE APPLICATION OF POINTS IN LANDSCAPE DESIGN}

In modern landscape art, the concept of point is relatively speaking. The factor of point usually exists in the form of "scenic spot", which is a material image with aesthetic value. Relative to the large area of the entire landscape, the scenic spot is a point concept.

In landscape design, many points are gathered together to form the linearization and complanation of points.

\section{A. The linearization of points}

The linearization of points is the continuous arrangement of points, which gives people a visual impact like a dotted line. The linearization application of points is more aesthetic, layered, rhythmic, and more moving than the direct application of solid lines ("Fig. $1 ")$. The use of point linearization to separate the space not only avoids the unobstructed view of the line of sight, but also plays the role of space separation. At the same time, the point linearization doesn't completely separate the two spaces like a solid wall. Wind, sunlight, air, and sight can penetrate to a limited extent. The two spaces are divided and connected, they are divided but not separated, which makes people have unlimited reverie and enriches the level of space.

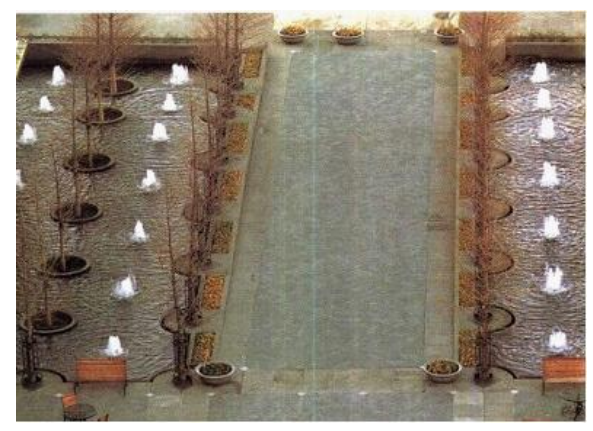

Fig. 1. The linearization of points.

Image source: Lighting the Light of Structuralism - Dan Kiley, China Architecture \& Building Press 2001.1

\section{B. The complanation of points}

The complanation of points ("Fig. 2", "Fig. 3") is a collection of most points, which is easy to produce a sense of plane; in the landscape design, the density of 
points are arranged differently, which will produce changes in light and dark. The uniform and repeated use of points will form a rigorous structure with strict order, which helps to exaggerate the serious and solemn atmosphere.

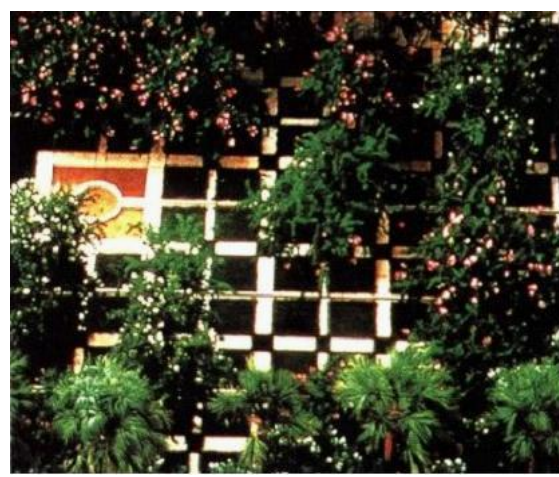

Fig. 2. The complanation of points.

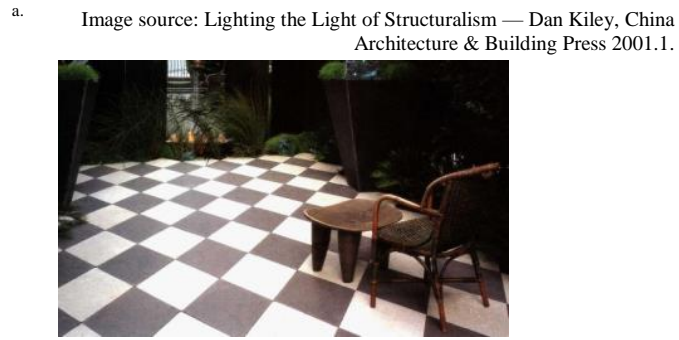

Fig. 3. The complanation of points.

a. Image source: Tofer Delaney, China Architecture \& Building Press 2002.

\section{THE APPLICATION OF LINES IN LANDSCAPE DESIGN}

\section{A. The concept of lines}

A line is the movement of a point in one direction. Lines in landscape design can be understood from three perspectives.

1) The path: It is the road in the landscape, it can be used as a tourist route with a traffic function, but also as a structural guide for the landscape ("Fig. 4").

2) The boundary line: It is the contour line of each landscape element, the skyline of the landscape or the boundary line of different mass plane, such as the boundary between land and lake. The contour lines of landscape elements are everywhere, ranging from the skyline and the shoreline, the contours of buildings and plants, and the contours of flowers and sketches ("Fig. $5 ")$.

3) The pattern line: It refers to the pattern line on the landscape element material, such as the pattern on the wall of the landscape wall.
According to different shapes, the line can be divided into two types: straight line and curve.

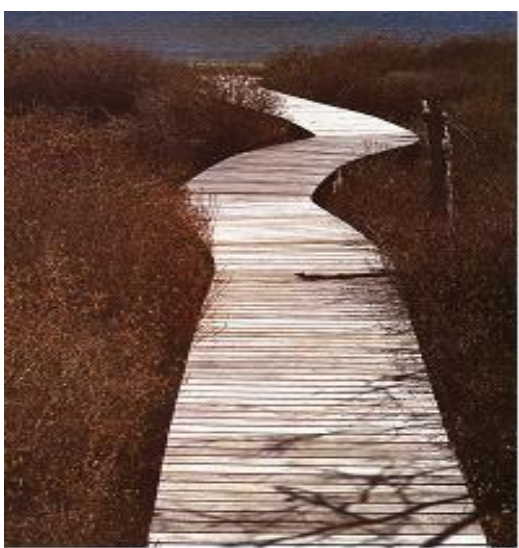

Fig. 4. Path line.

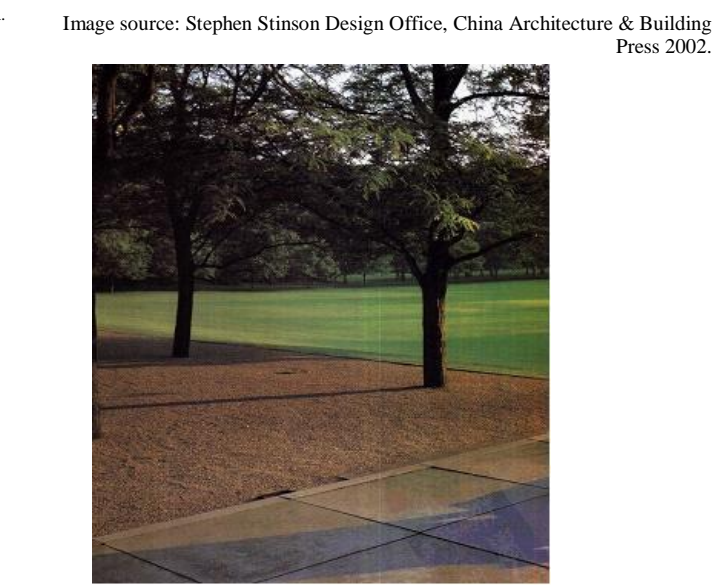

Fig. 5. Boundary line.

Image source: Lighting the Light of Structuralism — Dan Kiley, China Architecture \& Building Press 2001.1

\section{B. The application of straight lines}

"Straight lines often give people the feeling of being hard, upright, simple, calm, tough, tenacious, and bright, with the characteristics of speed, strength, and masculine beauty. The straight line has a strong sense of direction, and its strength is greater than that of a curve, so the straight line shape gives people a strong and powerful aesthetic. Straight lines are the easiest to blend with the lines of buildings" [1].

Straight lines include vertical lines, diagonal lines, broken lines and radial lines.

1) Vertical lines: Vertical lines often give people a visual experience of upright, upward and sublime, and can create a serious, upward, sublime and solemn atmosphere in the design ("Fig. 6"). 
2) Horizontal lines: Horizontal lines will make people feel open, stable and ease ("Fig. 6").

3) Diagonal lines: The diagonal line is a kind of straight line, which is relative to the direction of most straight lines in the landscape plane. The application of diagonal lines is in sharp contrast with the traditional symmetrical and steady composition. In the past, people were accustomed to symmetrical and balanced layouts, but nowadays, the large number of applications of diagonal lines and their asymmetry and unevenness give viewers a strong visual experience. The appearance of diagonal lines brings a lot of sharp corners, which gives people a strong sense of stimulation and arouses people's attention. It will naturally leave a deep impression in people's hearts, and will bring rich changes to the overall space ("Fig. 7" and "Fig. 8").

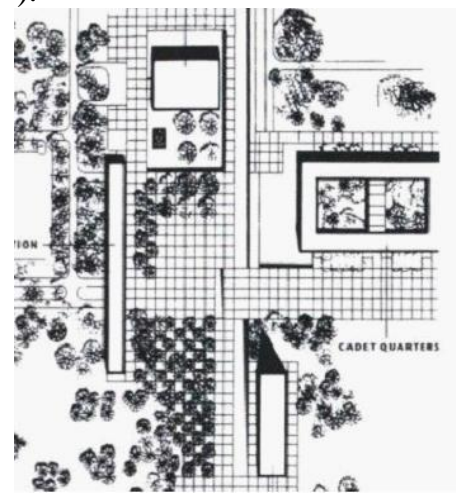

Fig. 6. Horizontal and vertical lines.

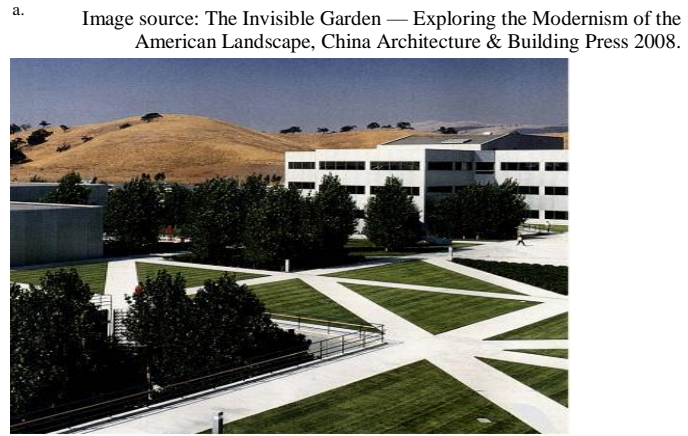

Fig. 7. Diagonal line.

Image source: Peter Walker, Dalian University of Technology Press 2006.

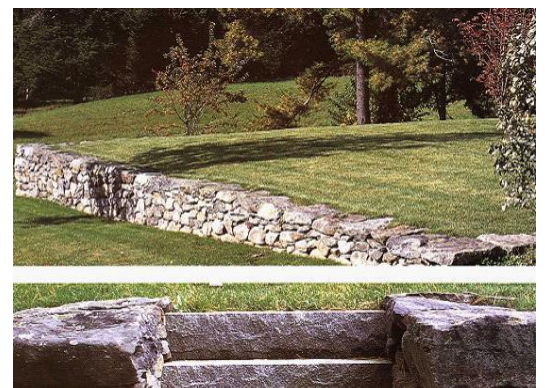

Fig. 8. Diagonal line.

Image source: Stephen Stinson Design Office, China Architecture \& Buildin

4) Broken lines: The broken line is also a kind of straight line. It changes the original line in the same direction and extends it in another direction. The change of direction produces a broken line. The brokenline path in the plane increases the length of the tour route, produces multiple visual angles, and creates a spatial effect of moving sceneries with moving steps. Different turning angles and turning methods greatly enrich the dynamics of the line, creating infinite spatial levels in a limited space. ("Fig. 9")

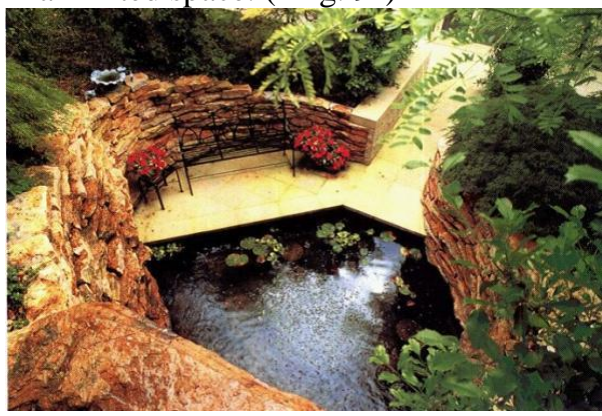

Fig. 9. Broken line.

Image source: Lighting the Light of Structuralism - Dan Kiley, China
Architecture \& Building Press 2001.1.

5) Radial lines: A radial line is a common natural line, such as sunlight, pine branches, etc. There are two ways of expression of radial lines in landscape design. One is that the plane is centered at a point, and the path is radial to highlight the center to create a focus effect. (A typical representative is the Palace of Versailles in France). The other is the cone-shaped landscape structures in the space, such as pavilions and frameworks. A radial line gives people a strong focus and guidance quality in space.

\section{The application of curves}

Curves with strong fluidity usually give people an elegant, smooth, brisk, plump, lively, and soft feeling, and they have the characteristics of flexibility, softness and feminine beauty. 
1) Geometric curves: Geometric curves generally have a sensible and soft aesthetic, usually symmetrically distributed, balanced, stable and full of change, making people experience a kind of rationality, flexibility, unicity and regularity, and giving people a sense of liveliness and vitality with very strong vitality. The common geometric curves are serpentine curves, spiral lines and camber lines.

a) Serpentine curves: It is also called the Sshaped line, and the British painter Hogarth called it the most beautiful curve in the book "Analysis of Beauty". The twists and turns of the serpentine curves have a strong sense of rhythm, and at the same time full of soft and beautiful temperament. In landscape design, serpentine curves are often used to shape the contours of water or flower belts.

b) Spiral lines: The spiral line has a strong sense of ascent, which perfectly combines repetition and creativity, and is extremely interesting. The sense of movement of the spiral line is strong but not nervous, with a gentle and gradually extending graceful beauty ("Fig. 10").

c) Camber lines: The camber line is a part of the circle, and there is a rigorous incomplete beauty. ("Fig. $11 ")$

2) Free curves: The free curve is light, lively, casual, soft, and extremely expressive ("Fig. 12"). In landscape design, there are many free curves, especially in natural-style landscape design, pools, stones, etc. are all forms of free curves. Most free curves are drawn at will, allowing people to experience the ups and downs of liquidity, diversity and vitality of life, giving people a feeling of softness, smoothness, and freedom. It can be elegant or majestic in beauty, which depends on the difference in the strength and dynamics of the free curve, and it is also related to the effect of the free curve and other forms. The free curve has randomness and contingency. The combination of free curves and geometric curves can often enhance its beauty; if the free curves match the diagonal lines, it will appear more imposing. However, the free curve is not easy to master, and if it is not used well, it will give people an impression of discursive feeling, disorder and lack of aesthetics.

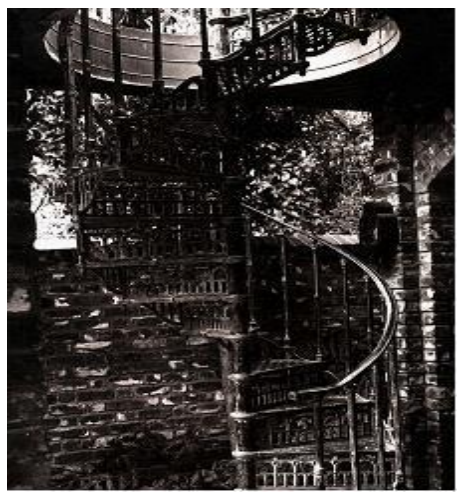

Fig. 10. Spiral line.

Image source: Tofer Delaney, China Architecture \& Building Press 2002.

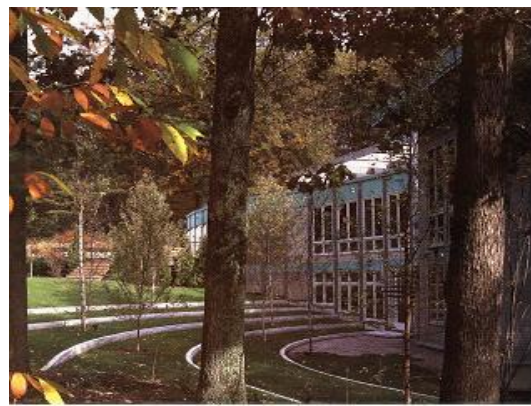

Fig. 11. Camber line.

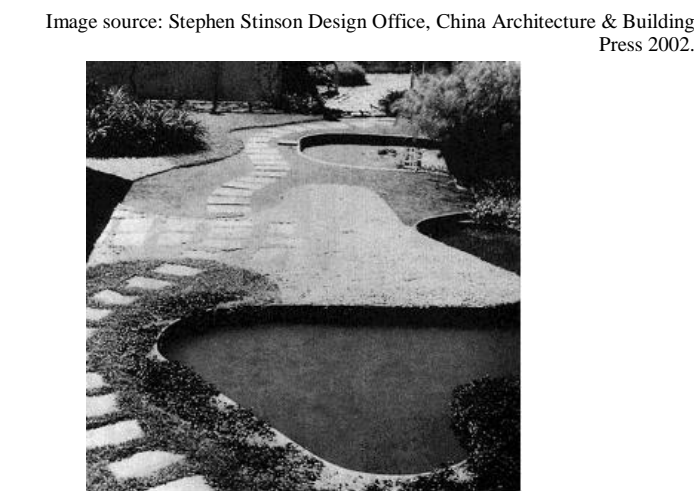

Fig. 12. Free curve

Image source: The Invisible Garden — Exploring the Modernism of the American Landscape, China Architecture \& Building Press 2008.

\section{THE APPLICATION OF THE PLANE IN LANDSCAPE DESIGN}

A plane is a trajectory or collection of points and lines, which can be divided into two types: regular and irregular. Regular plane includes circular plane, triangular plane, square plane, polygonal plane, etc. The irregular plane is free in form. 


\section{A. The regular plane}

1) The circular plane: When a line segment rotates in a plane around its one end point, the trajectory of its other end point is called a circle. A circle is a closed periphery geometric figure composed of countless tangents. It has the most introverted and tense characteristics in the image. It is stretched, smooth, soft, round, lively, harmonious, perfect... It contains a wealth of beautiful philosophy. The circle attracts people's attention, makes it easy to form a visual center of gravity, and is easy to harmonize with the surrounding environment ("Fig. 13").

2) The triangle: A closed figure composed of three line segments that are not on the same straight line connected end to end in sequence is called a triangle. The equilateral triangle gives people a sense of stability, keenness, and markedness, while the inverted triangle has an unstable sense of movement. ("Fig. 14")

3) The square plane: The square has a sense of stability, simplicity, stability, cleanliness and regularity. The rectangle that meets the golden ratio is richer in beauty. ("Fig. 15")

4) The polygonal plane: Polygonal plane commonly used in landscape design includes hexagons, octagons, etc., which are infinitely close to a circle, between the roundness of a circle and the rigidity of a square ("Fig. 16").

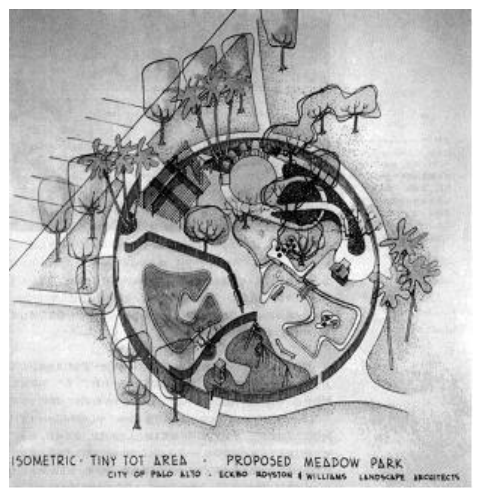

Fig. 13. Circular plane.

\footnotetext{
Image source: The Invisible Garden — Exploring the Modernism of the American Landscape, China Architecture \& Building Press 2008.
}

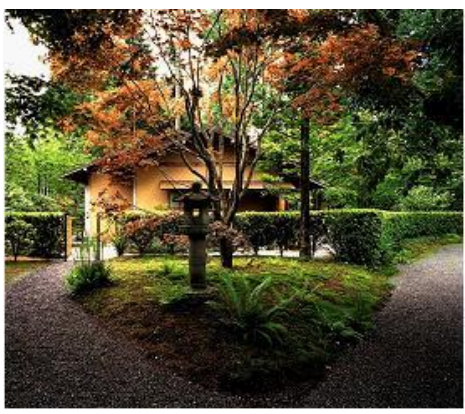

Fig. 14. Triangular plane.

a. Image source: Shunmyo Masuno, China Architecture \& Building Press 2002

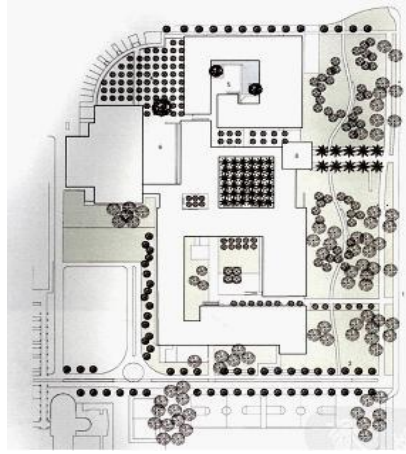

Fig. 15. Square plane.

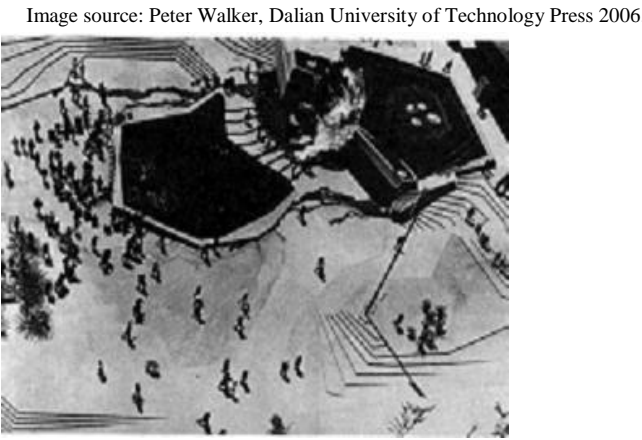

Fig. 16. Polygonal plane.

Image source: The Invisible Garden - Exploring the Modernism of the American Landscape, China Architecture \& Building Press 2008.

\section{B. The irregular plane}

The irregular plane form freedom is formed by the combination of irregular curves and straight lines, with greater differences in aesthetic attributes, greater flexibility than geometric shapes, less rationality, and more human touch ("Fig. 17"). The free plane is deeply loved by people because of its natural and unrestrained and random nature. It is the existence of free plane that enables modern landscape design to have a richer design language in addition to regular forms, and has a basis for innovation. 


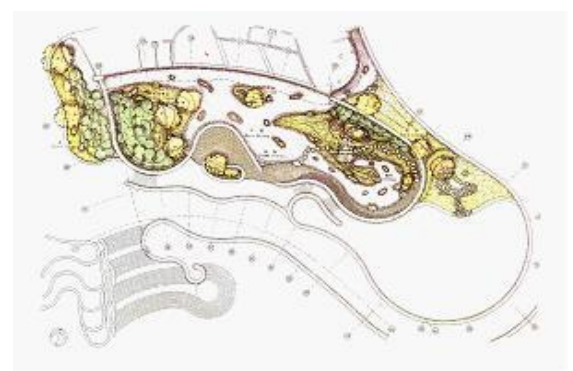

Fig. 17. Irregular free plane.

a. Image source: Shunmyo Masuno, China Architecture \& Building Press 2002.

\section{Conclusion}

The plane composition as the basis of art design is widely used in landscape design. Designers often abstract the specific elements of landscape design into points, lines, and plane, and then combine them in accordance with the rules of formal beauty to form design schemes with good visual effects. The application of plane composition in landscape design gives perceptual design a scientific and rational basis, and it also has stronger operability.

\section{References}

[1] [America] Edited by James G. Trulove. Jiang Kang, Li Jilong trans. Selected Works of Contemporary Foreign Famous Landscape Architects - Raymond Jongerius [M]. Beijing: China Architecture \& Building Press, 2002. (in Chinese)

[2] [America] Edited by James G. Trulove. Zhou Wenzheng trans. Selected Works of Contemporary Foreign Famous Landscape Architects - Mario Schjetnan [M]. Beijing: China Architecture $\&$ Building Press, 2002. (in Chinese)

[3] [America] Edited by James G. Trulove. She Gaohong, Tu Lei trans. Selected Works of Contemporary Foreign Famous Landscape Architects - Shunmyo Masuno [M]. Beijing: China Architecture \& Building Press, 2002. (in Chinese)

[4] [America] Edited by James G. Trulove. Cai Hong, Liu Xiaofei trans. Selected Works of Contemporary Foreign Famous Landscape Architects - Tofer Delaney [M]. Beijing: China Architecture \& Building Press, 2002. (in Chinese)

[5] [America] Edited by James G. Trulove. Chen Weidong trans. Selected Works of Contemporary Foreign Famous Landscape Architects - Michael Boltons [M]. Beijing: China Architecture $\&$ Building Press, 2002. (in Chinese)

[6] [America] Edited by James G. Trulove. Chen Weidong trans. Selected Works of Contemporary Foreign Famous Landscape Architects - Stephen Stinson Design Office [M]. Beijing: China Architecture \& Building Press, 2002. (in Chinese)

[7] [America] Edited by Jane Brown Gillette. Yao Xianghong and others trans. Peter Walker [M]. Dalian: Dalian University of Technology Press 2006. (in Chinese)

[8] Edited by ICI Consultanta. French Landscape Design [M]. Shenyang: Liaoning Science and Technology Press, 2007. (in Chinese)

[9] Edited by Xia Jiantong. Image source: Lighting the Light of Structuralism - Dan Kiley [M]. Beijing: China Architecture \& Building Press, 2001. (in Chinese)
[10] [America]Edited by Peter Walker, Melanie Seamer. Wang Jian, Wang Xiangrong trans. The Invisible Garden - Exploring the Modernism of American Landscape [M]. Beijing: China Architecture \& Building Press, 2008. (in Chinese)

[11] Edited by the German Association of Landscape Architects. Liu Ying trans. German Contemporary Landscape Design [M]. Beijing: China Architecture \& Building Press, 2011. (in Chinese) 